查等工作，亚在熟悉了實際情况，搜集到大量賽 際材料之後，才針對現貫存在的問題來開始自己 的科學做究。有些報告則是經過相當長的調查路

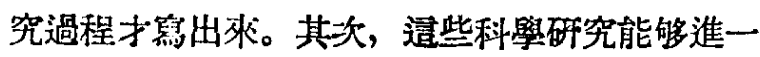
步聯系實際，是與有關部閏的支持和素助分不開 的。由於他們經常地、系統地供給䁈際材料，大 大增强了譄些論文的現實性。第三，應歸功於蘇 聯專家的提倡與指導。蘇聯專家不僅以蘚聯的先 進科學武裝了該校的敎師，並且在敎師們獨立的 科學研究中，給予具體的指導與禁助。同時，他 們本身的科學活動和對科學的嚴畫態度也就是我 們學黙的榜樣。最後是學校領導的重視和加强領 㝵。把科學研究工作制度化、經常化，制訂切實 可行的嚴密的全校科學研究總計劃、研室計劃 和個人計劃, 進行監督和檢查, 並保證計劃的實 現, 這也是取得成樍的主要原因之一。

這次科學討論會踓然取得不少成績, 但份你 在着很多缺點。主要的是論文一般地結合實際還 不够, 對實際掅况的調查研究進行的也僈不够經
常、系統和深入; 因而有多數論文愳顯得內容售 之, 科學的論證不够充分, 說服力也就不强。其 原因，一方面是由於科學水平的限制，另方面世 是由於進行科學研究的經常性和系統性不够。雖 然學校領導上在大力提倡, 但有的論文則仍是在

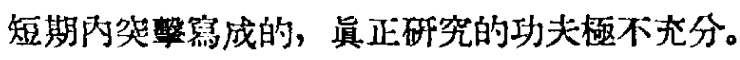
這也就具體指出了今後的道路和方法一一經常、 周密、菜統、深入的調查研究, 應作雼科學研究 的基礎。

中國人牫大學第四次科學討論會已 經閉幕 了。目前該校正在進行工作總結, 肯定成精, 指 出缺點, 交流經驗, 並開始質行科學作業的評選獎 㰮，藉以推動全校数師在科學道路上努力前進。 隨着较師科學水本的逐步提高, 在今後不雒的努 力下, 將一定會產生出具有較高科學水平的研究 成果, 使學校的科學研究工作逐漸得到更大的成 績。

（中國人民大學研究部科量研究科）

\title{
“中華地理誌”的編輯工作在積極開展中
}

1953 年起, 中國科學院展開了中華地理誌的 粫輯工作，內分自然地理與經㵂地理兩部分，全 急共約 100 萬字。這是一項棕合性工作, 自然地 理由中國科學院地理硼究所、地球物理研究所、 土堙研究所、植物研究所、動物研究室等單位聯 合給輯, 預期 1955 年底喘出初稿; 經湾地理由中 國科學院地理研究所與中國人民大學經濟地理教 研室合作進行, 預期 1957 年繃出初稿。

編輯中華地理誌的目的, 在於滿足中外人士 日焦堦長的對我們祖國認識的要求。目前我國的 地理著作，多牛是中學敎本或其同級的讀物，這 顯然是非常不矽的。大學地理敉師與文化水平較 离的國家工作人員, 都迫切需要一体便於參考,

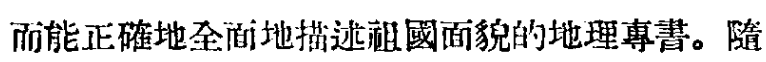
着我國在國際地位上的日趋重要, 隨着和平瓦主

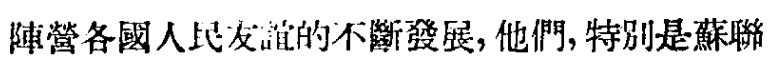
人包都熱烈地要求對我國有一深刻的認識。1952 年秋李, 蘇聯科學院地理研究所副所長沙訨薮柯
夫來我國考察時, 曾建議中國科學院進行編輯中 華地理誌的工作。

依照沙伊奇柯夫的意見: 中萍地理誌不㗹泣

"是普通的大學敉科書, 而應該是總結地理知識的 科學研究專著, 應該具有高度的政治思想水本與 科學水平，應該反胦出新中國社會政治結構的根 本改變以及與之有關的經㴤、文化建設的偉大成 就, 應該廣泛地組織經過檢查的實際材料, 顯示 各種現象的相互關係及其發展規律。除了批判地 利用現有的地理文缺外，還應派遗考察隊到各個 地路搜集補充材料。由於這部書要聯合有關地理 各個專業單位共同進行, 因此組織工作是比較複 雜熯巨的。

中國科學院根據沙侎奇柯夫问志的建㼁, 在 烓可楨副院長領導下, 開展了中華地理億的緛輯 工作。到目前,一共組織了 30 人左右的絽輯力量, 自然地理部分由中國科學院地理研究所研究員維 開富任總編輯，內分地形(領䎪人周廷儒)、籍候 


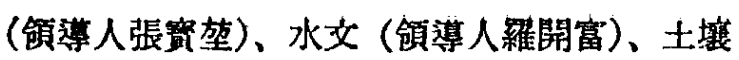
（䕘導人馬溶之）、植物（領導人鍼岕澍）、動物

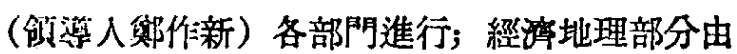
中國人民大學經濟地理敉研空主任孫敬之教授任 總縟輯。

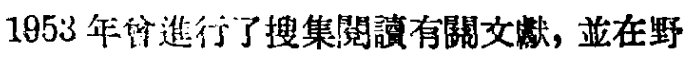
外作了一些補允調查的工作。我國地理學的基礎 是十分涝弱的, 在自然地理學中，氣候學和土壤 地理學會經進行過總結性工作，資料與人才也比 較集中，焂件是比較好的，但缺资資料的“空白” 地區還非常廣大。地形學的材料主要倚靠地質報 告中附帶描述的地形情况, 而認真的地形研究工 作只在極少数的地區進行過。水文紀錄在解放後, 經過宁整編策集，克服了反動的國民黨統治時代 的混微現象，但對各個河流的情况的分析研究則 阙在開始，材料也不完備。植物與動物朴料極大 部分是探集分類的材料，而缺乏生態的說明，動 物地理學的基礎特别薄弱。在經注地理方泊，有 用的資料，遠不如自然地理，一方面由於近代中

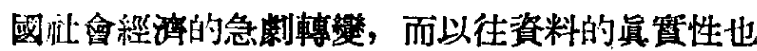
很差; 另一方面奮中國經济地理學又深受歐美資 產階級反動思想的毒害。因此, 如果說自然地理 的編輯工作主要依靠總結現有材料, 而野外調查 只常作㭪充手段, 則經濟地理的編軹工作主要是 捚集㭪光新材料，其次才是寥考崔材料。由於這 情情况, 經沾地理䋧輯進度, 就要比自然地理緩 摱一些，要遲二年才能絧出初满。

1954 年中華地理誌進入編寫初 稿（綜 合 調 查）的階段。編䳆過程是先分區描述，然後總論
全國。自然地理方面，在各部阴分區棕合的基磷 上, 将全國試劃篇七大自然塸域,即: 松黑區(東

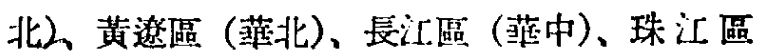
(蓝南)、蒙新區、青藏區和康寘區(横斷川地)。 這個劃分草案與過去劃區的最大不同點, 在於把 遼東牛島興遼河平原劃入萍北區队（根據水文、 土壤、植物、動物等情况)，華中與苝南的界線移 至北回歸線附近（熱帶與亞熱帶的界線）而不用

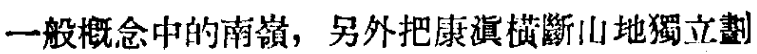
篇一個大區。現在正着手縟輯菲北區初稿, 预期 今年底編出東部濕潤區域的四大區初稿。經沙地 理方面, 由於我國計劃建設進行不久, 經営區域 息没有顯著形成，分區辦法暫時只能跟着行政區 走。1954 年內潐備編出華北區與內蒙古自治區的 初稿，並開始萧東區的材料搜集工作。

在中茫地理誌縓軦渦程中, 遇到了不少困鹳。 除前述資料不足的情况外，主要是工作人員缺乏 編輯最遙樣一部称合性巨䓔的經驗，特别由於人 力和材料興各部門領拳人分散在各研究單位，思 想行動不易統一。但是經過 1954 年1月劃分自然 區域的討論，各部門初步樹立了互相帮助，密切 合作的思想，從而修正了計劃，統一了步調，同 時，由於中央農業部和中央水利部等單位對於自

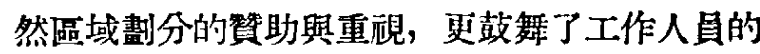
情緒, 這說明了中菲地理誌菂編輯研究工作在經 濟建設中是有其重要意義的。

\section{（中國科學院地理研究所 施雅風）}

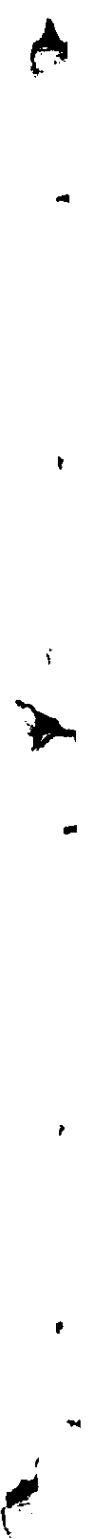

